\title{
Vývoj standardizace profese učitele v České republice - nekonečný příběh?
}

\author{
Karel Rýdl \\ Univerzita Pardubice, Fakulta filozofická
}

„Kvalita je hrdost člověka na vlastní práci.“ (W. E. Deming)

\begin{abstract}
Abstrakt: Př́spěvek popisuje vývoj standardizace a normalizace profese učitele $v$ průběhu 20. století $z$ hlediska sociálních potřeb a politických cílů. Zájem je věnován snahám o standardizaci profese učitele po změně režimu v průběhu posledního dvacetiletí. Autor jako očitý svědek a jako přímý aktér vysvětluje tehdejší představy o standardizaci profese učitele s důrazem na její pedagogická východiska.
\end{abstract}

Klíčová slova: profese učitele, standard, kariérní řád, historický vývoj, vzdělávací politika

\section{The Development of Standardization in the Teaching Profession in the Czech Republic - a Neverending Story?}

Abstract: The paper describes from the point of view of a social needs and political aids and goals the development of a standardization and normalization of the Teacher's profession during the 20th century. The main interest focuses on the standardization after the regime change twenty years ago. Author as the eyewitness and the co-creator tries to explain the ideas of the standardization of the teaching profession from the point of view pedagogical roots, developed during the years 2008-2009.

Keywords: teaching profession, standardization, career rule, historical development, educational policy

V tomto přispěvku jde mnohem více než o objektivizující analýzu na základě historikova odstupu od tématu o subjektivní př́stup k tématu, kterého byl autor určitou dobu shodou okolností prímým účastníkem. Jeho smyslem je, aby byl budoucími historiky brán jako jeden z četných pramenů narativní povahy nejen $\mathrm{k}$ tématu standardizace, ale i době charakterizované přeléváním snah vzdělávací politiky oscilující mezi mírou autonomie školství a učitelů a jejich centralizovaným ř́zením převážně politického a méně profesního charakteru. Problém standardizace profesní činnosti učitele nemúže být uspokojivě vyřešen shora, politickou mocí, ale jen a jen zdola za účasti prímých aktérů pedagogického působení, protože jde o bytostně odborný problém, jemuž mohou prozíraví politici pouze vytvářet či nevytvářet podmínky. I o tomto problému pojednává následující text.

Likvidací centralizovaného systému řizení školství po listopadu 1989 byly zrušeny také tzv. komplexní hodnocení učitelů, která ve dvouletých periodách prováděli ře- 
10 ditelé škol za účasti školních inspektorů a pracovníka místní organizace KSČ. Jejich smyslem bylo zjistit, zda učitelé vykazují dostatečnou míru nejen pedagogické profesní zdatnosti, ale především požadované míry loajality vưči socialistické společnosti, byt' spíše ve formální podobě. ${ }^{1}$ Tato „hodnoceni“" byla koncem 80 . let minulého století čím dál tím více formálnější a jen málo vypovídala o skutečných kvalitách učitele. Tehdejší „hodnotící kritéria“ byla orientována více na vnější projevy jednání učitele v souladu s tehdejší „doktrínou komunistické výchovy“.

Jistá forma pojetí profesní úrovně učitele existovala již v Československu v meziválečném období 20. a 30. let. Podmínky a formy vymezoval Zákon o správě školství ze dne 9. dubna 1920, č. 292 (srov. Rýdl, 2010, s. 15). Jednalo se hlavně o posuzování kvality učitele, který se musel sám dožadovat kariérního postupu na základě vlastního přesvědčení o dostatečné profesní zkušenosti. Tyto osobní žádosti ve formě přehledového výpisu profesních činností žadatele posuzovaly samosprávné orgány tehdejšího školství, totiž na základě doporučení místního školního výboru projednala žádost komise okresního školního výboru, která věc posunula s vlastním názorem zemské školní radě a ta vydala definitivní rozhodnutí (Rýdl, 2010, s. 16). Začínající učitel (po maturitě na učitelském ústavu) byl nucen žádat o povolení hospitace na národní škole, která byla předpokladem k vykonání doplňovací zkoušky učitelské dospělosti. Dále musel žádat o přijetí do počáteční služby učitelské (výpomocný učitel, praktikant) na národní škole a to na základě profesního životopisu. ${ }^{2}$ Pokud se kandidát sám cítil na vykonání zkoušky učitelské způsobilosti pro vyšší typ školy (měšt’anská škola), musel o připuštění ke zkoušce žádat podle stanovených předpisů a podmínek. ${ }^{3}$ Profesně kvalifikační zkoušky byly potom konány před komisemi ve vybraných městech. Po úspěšném složení zkoušek se mohl kandidát ucházet jinou žádostí o místo definitivního učitele, které bylo obsazováno konkurzem. ${ }^{4}$

Pro nastupující středoškolské profesory byla v roce 1922 zavedena tzv. zkušební praxe. Kandidát na místo byl přiřazen ke zkušenému profesorovi, u kterého hospitoval minimálně šest hodin týdně a žádoucí bylo navštěvovat i vyučovací hodiny jiných profesorů. Uvádějící profesor musel u kandidáta hospitovat minimálně jednu hodinu týdně a dohližžel na veškeré jeho pưsobení ve škole. Kandidát musel od roku 1928 absolvovat týdně minimálně 19 naukových nebo 22 jiných (tělocvik, výtvarná a hudební výchova) vyučovacích hodin.

Po roce 1948 byl učitel chápán stejně jako celé školství jako součást ideologické kontroly obyvatelstva. Jeho pedagogické kvality byly posuzovány sekundárně, pokud vůbec vyhověl primárně hodnoceným kvalitám ideologické pevnosti a loajality vůči vládnoucímu režimu. Jak již bylo uvedeno výše, tyto „kvality“ byly koncem 80. let již zcela formální a kromě stranických funkcionářủ a profesních kariéristů je již nikdo nemohl ani brát dostatečně vážně.

1 V př́saze nastupujících učitelů část textu zavazovala učitele respektovat vědecký světový názor, aby z žáků vyrostli platní členové socialistické společnosti, ale vědecký světový názor nebyl konkretizován a $v$ podstatě nikdo také nekontroloval, co vlastně učitel v hodinách vyučoval.

2 Výnos MŠANO ze dne 19. července 1935, čís. 92.252-I. In Věstník MŠANO, XVII, 1935, s. 172.

Výnos MŠANO ze dne 23. ledna 1935, čís. 56.827/34-I. In Věstník MŠANO, XVII, 1935, s. 35.

4 Prováděcí předpis MŠANO č. 306. In Věstník MŠANO, XIII, 1931, s. 58. 


\section{Deklarace standardu profese učitele jako pilíře vzdělávací politiky - trend standardizace od 90 . let 20 . století}

$\checkmark$ průběhu první poloviny 90 . let dospěl trend standardizace procesů a cílové představy výkonu v různých oblastech lidské činnosti pod tlakem ekonomických indikátorů pojetí kvality (i když spiše výkonu) i do oblasti školství. Téměř všechny země OECD a řada dalších ekonomicky vyspělých zemí světa již měla nebo rychle připravovala vhodně formulovaný standard profesních činností učitele, který by se stal účinným nástrojem pro hodnocení kvality výkonu činností učitele a zajišt’oval by učitelům minimální míru profesní jistoty. Na druhé straně by přijetí standardu, stejně jako i v jiných oblastech společenského života, přineslo zavedení rádu, pořádku a odstranilo by jistou míru chaosu, a to i za cenu jisté míry omezení spontánní tvořivosti učitele. Zároveň ale bylo nutné respektovat podporu silné míry pocitu sebeodpovědnosti a spoluodpovědnosti všech aktérů výchovných a vzdělávacích procesů. Začalo se hovořit o účelnosti a smysluplnosti standardizace procesů, činností i výstupů.

$\checkmark$ České republice se $v$ téže době rozvíjela diskuse o míře autonomie $v$ oblasti školství a vzdělávání a o obsahu vize nově formulované vzdělávací politiky, do které vstoupil nový fenomén, totiž vedle kompetencí státu (po ztrátě monopolu na řízení školství) i kompetenční odpovědnost regionálních institucí, jako výraz demokratizace a liberalizace podmínek organizace státní, veřejné a privátní moci, což se projevovalo v diskusích o reformě veřejné správy, řízené Ministerstvem vnitra ČR, která byla dokončena a prosazena $v$ roce 2001. Tato reforma poskytla jasné rozdělení kompetencí mezi stát a regiony, rrízené krajskými a potažmo obecními úřady různých stupňů.

Po několika letech „divoké“ liberalizace a autonomizace českého školství v 90 . letech se od jejich 2. poloviny začala vytvářet dosti jasná představa o rámci vzdělávací politiky a roli státu $v$ ní. $V$ roce 1996 byl vyhlášen ministerstvem školství projekt „Učitel“, který byl na tehdejší dobu velmi dobře připraven obsahově, včetně prvotních představ o spojení profesního standardu s kariérním systémem pro učitele. ${ }^{5}$ Projekt nebyl ovšem, jako řada dalších velmi dobrých aktivit $v$ oblasti školství, finančně rádně zajištěn a tak řešení podoby nového pojetí identity učitele ve smyslu jeho profesionalizace $v$ podstatě ztroskotal. Jistý vliv na neúspěch projektu mohl mít také vnitřní paradox, obsažený v cílech projektu „Učitel“, totiž chápání učitele jako strážce společenských hodnot na straně jedné a jako prosazovatele změny na straně druhé. Vzhledem $\mathrm{k}$ dosavadnímu pojetí pregraduální př́ípravy učitelů nebyli učitelé v praxi na podobný př́stup k chápání vlastní role vůbec připraveni. Odpůrci standardizace poukazovali i na rizika omezování dosažené pedagogické a didaktické autonomie učitelů. V době vytrácení se euforie z projektu „Učitel“ byla zahájena činnost nad první vizí české vzdělávací politiky.

5 V situaci, kdy učitelské a pedagogické asociace a neziskové organizace s jistou podporou státních a zákonodárných institucí neúspěšně bojovaly za prosazení myšlenky profesní pedagogické komory, byla myšlenka zajištění profesních jistot jiným způsobem velmi aktuální. 
Po nutných komparativních analýzách stavu českého školství a vzdělávání se zahraničím (ÚlV, 1999), byla týmem odborníků v čele s Jiřím Kotáskem zpracována první komplexní představa o směřování českého vzdělávacího systému s názvem „Národní program rozvoje vzdělávání v ČR“, známého spiše pod názvem „Bílá kniha“ (2001). Na jejím základě zpracovalo MŠMT dosti ambiciózně znějící Dlouhodobý záměr realizace, který nebyl dodnes naplněn a zůstal tehdy velmi nadějným, ale politicky $v$ tichosti umlčeným ojedinělým výkřikem naděje. Další aktivity MŠMT jsou spojeny s tematickými projekty rezortního výzkumu, mezi nimiž byl pro roky 2000-2001 vyhlášen i projekt s názvem „Podpora práce učitelư“. Tento projekt vyústil v návrh modelu profesionalizace činnosti učitele s nádechem nutné míry normativnosti a receptivnosti, což souviselo s tehdejšími zvnějšku vynucenými proměnami pregraduální př́pravy učitelů a dalších odborníků na vysokých školách v důsledku prosazování tzv. boloňské deklarace z roku 1999, která vyústila $v$ často neorganické a formální členění studia do tří úrovní (bakalářské, magisterské a doktorské), pro které (zejména bakaláře) ale např. v rezortu školství nebyla vytvořena pracovní místa. Projekt „Podpora práce učitelů“ navrhl i rozvojový koncept ve smyslu systému dalšího vzdělávání absolventů pregraduální př́pravy na fakultách připravujících učitele. Velkým a málo doceněným výstupem tohoto projektu bylo rozvinutí diskuse nad zahraničními zkušenostmi v oblasti vlivu systému dalšího vzdělávání na kariérní systém pro učitele. $V$ roce 2001 byly výstupy projektu představeny na celostátní konferenci a ve dvoudílné publikaci koordinované E. Walterovou (2001). V prvním díle této publikace byl zveřejněn také návrh J. Vašutové (2001, s. 19-46) na profesní standard učitele, který popsal obsahy a vzájemné vztahy mezi kompetencemi, standardem a kvalitou jako triády profesionalizace učitele. Představa J. Vašutové vycházela ze čtyř vzdělávacích cílů formulovaných $v$ roce 1996 J. Delorsem (učit se poznávat, učit se žit, učit se jednat a učit se být), kterým odpovídaly čtyři funkce školy (kvalifikační, socializační, integrační a personalizační). V práci učitele se potom tyto cíle a funkce odráži v jeho profesních kompetencích, kterých na základě „39 klíčových kompetencí pro Evropu“ vymezila J. Vašutová celkem 19.6 Vašutová zde také uvedla zahraniční zkušenosti sousedních zemí (Slovensko, Mad'arsko, Polsko) jako argumenty pro přijetí standardu českou vzdělávací politikou. To se $v$ ČR nestalo, zatímco na Slovensku byl prakticky využit, bohužel téměř bez respektu k autorským právům autorky. Postupně byla diskutována i oblast počtu kompetencí ve smyslu profesních požadavků na učitele (srov. např. Švec, 2002). Tehdejší situaci okolo standardizace profese učitele shrnula K. Suchánková (2007).

Jedním z výstupů projektu rezortního výzkumu MŠMT „Podpora práce učitelů“ byl i „Návrh profilu absolventa učitelského studia na VŠ“, který byl vysokými školami bez valného dalšího výsledku diskutován na jaře 2003 a ke kterému se zřejmě vrátí současné diskuse o zásadní proměně efektivity pregraduální př́pravy učitelů v souvislosti se změnou funkce a role školního vzdělávání. ${ }^{7}$

6 Klíčové kompetence pro Evropu byly formulovány skupinou expertů Rady Evropy v roce 1996. Jejich přehled uvádí také studia České vzdělání a Evropa (Praha, 1998).

7 Dopis Odboru vysokých škol děkanům fakult vysokých škol připravujících učitele z 28. března 2003, č.j. 15879/2003-30 s prílohou redukované podoby návrhu standardu profese učitele z dílny J. Vašutové z roku 2001. 
Vlivu standardu profese učitele na pregraduální přípravu se věnovaly dva výzkumné záměry. Na Pedagogické fakultě Ostravské univerzity koordinovala od roku 2002 výzkumný záměr s názvem „Nové možnosti vzdělávání učitelů, vychovatelů a žáků pro učící se společnost 21. století “ H. Kantorková. Na Pedagogické fakultě UK v Praze koordinovala V. Spilková výzkumný záměr s názvem „Učitelská profese v měnících se požadavcích na vzdělávání“. Oba se pokusily implementovat do českého pedeutologického prostředí nejlepší zkušenosti a koncepce pojetí učitele a učitelství ze zahraničí, snažily se vytvořit pořádek v definicích pojmů a vytvořit soubor návrhů pro prosazení nového paradigmatu vzdělávání učitelů nejen v kurikulární, ale i organizační a strukturální oblasti. V různých analytických studiích bylo poukázáno na fakt, že nikde $v$ zemích EU a OECD není problém řešen komplexně, ale jen a jen s větším či menším úspěchem $v$ jednotlivostech (kritéria výkonu funkce učitele či ředitele, potřeby učitele $v$ proměně funkce a role systému školství, minimální akreditační standardy přípravy učitelů, kariérní rád, funkce a role dalšího vzdělávání učitelů apod.). Problematice profesionalizace učitele bylo věnováno i monotematické číslo časopisu Pedagogika 4/2007. Výraznou podporou celého procesu podpory profesionality a kvality učitelů bylo v roce 2009 vytvoření Asociace profese učitelství (APU). Postupně také přebíraly nově vznikající návrh profesního standardu zaměřeného zejména na manažerské dovednosti učitelů, kterému budeme věnovat pozornost $v$ dalších částech textu.

Zajímavé a typické pro české prostředí bylo, že aniž by byl dohodnut odborně a politicky akceptovatelný model kariérního systému, který byl připravován péčí tehdejšího VÚP a MŠMT a řady externích organizací, byl v roce 2004 zanesen jako součást legislativních opatření do Zákona o pedagogických pracovnících, ovšem jen formálně a bez jakýchkoliv motivačních faktorů pro učitele. 8 Tento trend prosazení kariérního systému pro učitele „za každou cenu“ byl posílen nařízením Vlády ČR č. 533/2005Sb., jehož obsahem je katalog prací s potřebnými kvalifikačními předpoklady, což mělo významný vliv na změny v platových třídách zaměstnanců ve veřejných službách a správě. ${ }^{9}$

\section{Deklarace standardu profese učitele jako pilíře vzdělávací}

V následujícím roce 2006 nová vláda začala vytvářet dojem systémovější podpory dosavadních roztřrištěných představ a návrhů týkajících se standardizace profese učitele a jejího propojení s kariérním systémem. Tým nových poradců ministra školství Ondřeje Lišky posílený náměstkem ministra Jindřichem Kitzbergerem prosadil na základě předložených argumentů o nutnosti standardizace procesů pro další rozvoj vize vzdělávací politiky, jejíž podstatné části zejména v kurikulární

Zákon o pedagogických pracovnících č. 563/2004 Sb., § 29.

9 Tímto nařízením ze 7. 12. 2005 bylo zrušeno nařízení vlády č. 469/2002Sb. 
14 oblasti byly prosazeny do nového školského zákona. ${ }^{10}$ Aby byly cíle kurikulární politiky skutečně prosazeny zvnitřněným přijetím samotnými učiteli, bylo nutné posílit jejich sdílení vlastní profesionality definováním standardu kvality činnosti učitele. Postupně byly definovány funkce podobného standardu (rozvojová, regulační, motivační, gradační a sjednocující, které se měly stát základem nově pojatého tzv. kariérního řádu učitelské profese). Standard byl promýšlen jako důsledek měnící se podoby pregraduální přípravy učitelů a jako východisko, či odrazový můstek pro formulaci profesních kompetencí ve smyslu základního kritéria hodnocení kvality učitele a jeho činnosti (funkčnost systému dalšího vzdělávání učitelů). V průběhu roku 2007 byly vytvořeny minimálně dostačující rámcové podmínky pro vytvoření návrhu nového standardu profese učitele týmem odborníků z vysokých škol i běžné praxe regionálního školství. ${ }^{11}$ Profesní standardizace byla navíc podpořena řadou teoretických vědeckých studií, které vymezovaly světové trendy v oblasti pohledu na pojetí učitele z dílny např. F. Korthagena (2004), Evropské komise a na její studii navazující studie Evropského parlamentu o zvyšování kvality př́pravy učitele a z nově publikovaných zásad Evropského rámce kvalifikací pro celoživotní vzdělávání. ${ }^{12}$ Řešitelský tým vycházel z koncepce J. Vašutové z roku 2001 a respektoval zásadu, že každý proces by měl být nastaven na základě „nejlepší praxe“ (best practices), jak jej lze provádět. Tedy jde o již v praxi prověřenou zkušenost. Dále byla respektována zásada zastupitelnosti pracovníků a zásada, že standardizace by měla eliminovat nestandardní řešení a tím zrychlit procesy $v$ odpovědném rozhodování se.

Silnou inspirací pracovní skupiny při MŠMT byl dokument „Standard programu a práce učitele $v$ projektu „Začít spolu“, publikovaný v českém znění v roce 2002.13 $\checkmark$ něm byly vymezeny $v$ šesti oblastech indikátory a kritéria pro práci učitelů, které odpovídaly tehdejším (a i dnes aktuálním a perspektivním) požadavkům na výkon práce učitele z hlediska respektování osobnosti dítěte. Pro př́klad si je připomeňme: 14

10 Zákon č. 561/2004Sb.

11 V týmu Karla Rýdla dále pracovali: Pavel Brebera, Jana Kazíková, Hana Koštálová, Hana Lukášová, Michaela Píšová, Michaela Prášilová, Květa Suchánková, Vladimíra Spilková, Vladimír Srb, Hana Stýblová, Zora Syslová, František Tomášek, Petr Urbánek, Jaroslava Vašutová.

12 Srov. např.: Quality Assurance in Teacher Education in Europe. Brussels, EU-Eurydice 2006; Communication from the Commission to the Council and the European Parlament. Improving the Quality of Teacher Education. Brussels, 2007; Evropský rámec kvalifikací (EQF) pro celoživotní vzdělávání. Brusel, EU 2005 (DG EAC A/1/JBJ D) a konečně i Zpráva o zlepšování kvality vzdělávání učitelů přijatá Evropským parmalentem 23. 9. 2008. Tato Zpráva reagovala na rok před tím vydanou zprávu společnosti McKinsey \& Co. Pod názvem „Jak se vzdělávací systémy vykazující nejlepši výsledky dostávají do čela“.

13 Original edition Step by Step Program and Teacher Standards for Preschool and Primary Grades published in Hungary. Ceské vydání: @ Step by Step ČR, o.s., Praha 2002. Translation: Olga Kropíková, 2002.

14 Pokud v nich najdete inspiraci Montessori pedagogikou, tak jste na správné cestě. Program „Step by Step“ byl v USA silně ovlivněn právě efektivní praxí Montessori pedagogiky. 
1. Interakce učitel - žák

Interakce učitele se žáky jsou časté, pozitivní, partnerské, vstřícné, respektující individuální zájmy a zvláštnosti každého žáka.

\section{Zapojení rodiny}

Učitel a rodiče spolu úzce spolupracují jako partneři, aby zajistili optimální podmínky pro vzdělávání a rozvoj dítěte.

\section{Plánování na dítě zaměřeného programu}

Vzdělávací program je připravován tak, aby odpovídal individuálním potřebám a zájmům každého dítěte i zájmům a potřebám celé skupiny a aby poskytoval př́ležitosti pro pozorování a vyhodnocování pokroku každého žáka.

\section{Techniky smysluplného učení}

K podpoře smysluplného učení užívá učitel rozmanitých výchovně vzdělávacích metod, materiálů a pomůcek, které jsou přiměřené vývojové úrovni dětí a podněcují jejich individuální rozvoj i vzájemnou kooperaci.

\section{Učební prostředí}

Učitel vytváří podnětné prostředí, ve které dětem umožňuje realizovat rozmanité činnosti samostatně a spolupodílet se tak na vlastním vzdělávání.

\section{Zdraví a bezpečnost}

Při plánování a realizaci činností s dětmi respektuje učitel zásady bezpečnosti a ochrany zdraví dětí.

Profesní standard chápala naše pracovní skupina jako důležitý nástroj k výraznější profesionalizaci učitelů, která měla přispět ke zvýšení kvality jejich práce v intencích cílů zákonem podpořené kurikulární reformy. Standard se pokusil charakterizovat, jak by měla vypadat práce profesionála (měl umožnit odlišení jeho práci od práce více či méně poučeného laika). Měl srozumitelně popisovat základní úroveň kvality učitelské práce očekávanou (vyžadovanou) od každého učitele po 2-3 letech praxe. Byly popsány i vyšší úrovně kvality očekávané od vynikajících učitelů. Dosahování jednotlivých úrovní standardu mělo být provázáno s podstatným zvyšováním mezd učitelů jako jedním z motivačních faktorů prosazování dokumentu do běžné praxe školního vyučování.

Standard měl být podle slibů politiků provázán s komplexním systémem podpory učitelů a jejich profesního růstu, konkrétně zejména s přípravným vzděláváním učitelů, uváděním začínajících učitelů do praxe, mentoringem/kolegiální podporou učitelů, jejich dalším vzděláváním apod. Standard byl chápán i jako podklad k vytváření nezbytných podmínek pro kvalitní práci učitelů a měl tak vést k lepším výsledkům školního vzdělávání. Standard měl tedy smysl pouze jako jádro komplexního systému podpory učitelů. 
Standard kvality profese učitele byl chápán jako rámec profesních kompetencí, které jsou nezbytné pro kvalitní vykonávání profese v kontextu pojetí cílů, obsahu a strategií školního vzdělávání vymezených kurikulárními dokumenty. Profesní kompetence jsme považovali za flexibilní strukturu, která zahrnovala zvnitřněné znalosti, dovednosti, reflektované zkušenosti, postoje a hodnoty učitele. Tyto komplexní způsobilosti se měly projevit $v$ činnostech učitele.

Standard měl vymezit základní oblasti a $v$ nich charakterizovat odpovídající profesní činnosti učitele, které lze pozorovat a hodnotit. Za základní nástroje k hodnocení kvality práce učitele bylo považováno pozorování výuky, rozhovor s učitelem, rodiči a žáky, a analýza dokumentů (přípravy na výuku, práce žáků, portfolio učitele apod.).

Standard jako rámec požadovaných profesních kompetencí byl sice chápán jako určitá norma, ale ne statická a zafixovaná, ale naopak jako otevřený a vyvíjející se fenomén. Mělo jít o strukturu vzájemně provázaných prvků, které fungují jako celek. Standard jako nástroj k hodnocení a sebehodnocení neměl být chápán dogmaticky, ale holisticky, jako rámec sloužící k celkovému hodnocení kvality profesního výkonu učitele, ne nutně k posouzení všech jednotlivostí.

Z hlediska smyslu a funkcí standardu jsme považovali za důležité, aby sloužil především:

a) K ujasňování toho, jak se musí proměňovat pojetí profese (role a profesní kompetence), jak by měli být učitelé vzděláváni, aby zvládali požadavky spojené s výraznou změnou cílů, obsahu a metod školního vzdělávání. Tedy, co znamená kvalitní výkon učitelské profese $z$ hlediska současných i perspektivních nároků nejen $v$ domácím, ale i mezinárodním kontextu. Jde především o široce sdílené porozumění proměnám pojetí kvality učitele uvnitř profesní komunity, mezi politiky a širokou veřejností.

b) Jako sjednocující rámec pro vymezení profilu absolventa studia učitelství na fakultách připravujících učitele a jako východisko pro proměny v pregraduální př́pravě učitelů.

c) Jako východisko pro proměnu systému dalšího vzdělávání pedagogických pracovníků, jeho zacílení vzhledem k požadavkům kurikulární reformy a s ohledem na vzdělávací potřeby učitelů.

d) Jako nástroj pro oceňování kvality učitele s dopady na finanční ohodnocení a kariérní postup. Jednotlivé kariérní úrovně by byly propojeny s atestacemi, garantujícími naplnění definované úrovně.

e) Jako rámec pro systematickou reflexi vlastní práce, nástroj pro sebehodnocení a profesní rozvoj. Měl by motivovat učitele $\mathrm{k}$ tomu, aby se dále profesně rozvíjel $z$ vnitřní potřeby.

f) Jako základ k vytvoření systému podpory učitelů $v$ jejich profesním rozvoji včetně nástrojů jejich podpory (např. mentoring).

Pro konkretizaci představy o obsahové podobě návrhu našeho Standardu uvádím následující př́klad tří indikátorových oblastí: 
1.Výuka a kurikulum

1.1 Plánování (projektování) kurikula

1.2 Proces učení (realizace kurikula)

1.3 Reflexe (kontrola a hodnocení procesů a dosažených výsledků kurikula)

2. Vnější souvislosti výuky

2.1 Rozvoj školy, tvorba ŠVP

2.2 Klima školy

2.3 Spolupráce s rodiči, kolegy a veřejností

3. Osobnostní a profesní rozvoj učitele

3.1 Profesní znalosti (deklarativní, procesuální, kontextuální)

3.2 Profesní ctnosti (etická kritéria a kodex učitele)

3.3 Profesní autoregulace (nezávislost, odpovědnost)

Pro indikátor č. 1.1 (Plánování kurikula) byla navržena následující hodnotící kritéria:

1. Učitel vybírá cíle výuky a vyučovacích jednotek na základě znalostí očekávaných výstupů a oborových výstupů formulovaných v ŠVP tak, aby bylo možné procvičovat dovednosti zákonem vymezených klíčových kompetencí.

2. Učitel dokáže tyto cíle srozumitelně formulovat všem kolegům, žákům i širší veřejnosti.

3. Plánování vyučování učitelem vychází ze z jeho znalosti úrovně schopností, dovedností a postojů žáků a míry jejich porozumění učivu.

4. V rámci plánování vyučování učitel formuluje nástroje efektivního hodnocení míry dosažitelnosti cílů a zamýšlených aktivit.

5. Učitel provádí didaktickou analýzu učiva, hledá vztahy a propojuje učivo z různých vzdělávacích oblastí.

6. Učitel zařazuje do výuky činnostní aktivity simulující reálný život tak, aby vedly co nejvíce k porozumění učivu žáky a k rozvoji jejich klíčových kompetencí.

\section{Pro hodnotící kritérium č. 5 byly navrženy následující nástroje:}

a) Efektivní evaluační nástroje:

- Rozhovor s ředitelem školy nad vlastním portfoliem, hospitace.

- Periodická návštěva externího hodnotícího orgánu (např. Čšı).

b) Efektivní autoevaluační nástroje:

Vlastní portfolio, deník, videozáznam, zpětné vazby od žáků a kolegů z vlastní i jiných škol.

Důraz při formulacích standardu byl kladen na to, aby představa o kvalitě učitele vyjádřená profesním standardem byla vytvářena ve spolupráci představitelů školní praxe, pedagogického výzkumu a vzdělávací politiky. Zejména bylo důležité, aby se do jeho tvorby aktivně zapojili samotní učitelé, aby mohli ovlivňovat jak jeho celkové pojetí, tak konkrétní formulace. Tuto roli sehrály dvě kola veřejné diskuse. Klíčovou podmínkou k vnitřnímu přijetí standardu učiteli bylo, aby byl v souladu s tím, 
18 jak učitelé sami chápou podstatu své práce a jak vidí sami sebe jako profesionály. Pouze profesní standard, který je široce sdílený a zvnitřněný, může být pro učitele motivací a motorem ke zkvalitňování vlastní činnosti, což je v kontextu českého školství jedna z nejdůležitějších funkcí standardu. Byli jsme hluboce přesvědčeni o tom (a jsem přesvědčen dodnes), že tvorba Standardu má být „v rukou profese“ a že je tedy třeba umožnit učitelům, aby se mohli skutečně podílet na definování profesní kvality (nejen fiktivně, či dílčím připomínkováním - jak tomu bylo u nás mnohokrát v minulosti). Proces tvorby Standardu „zdola“ tak ale vyžaduje dostatek času. V prvních fázích společné tvorby je prioritou nalezení shody v celkovém pojetí Standardu, jeho smyslu a funkcích v kontextu proměňujícího se českého školství.

Proto naše skupina věnovala tak velkou pozornost vyvolání široké veřejné diskuze o tom, jak chápat kvalitní vykonávání učitelské profese v měnících se požadavcích na školní vzdělávání. Kladli jsme velký důraz na průběžné vyhodnocování veřejné diskuze a na pečlivou analýzu jednotlivých názorů. Konkrétní podoba profesního standardu byla $v$ této fázi věcí druhotnou. Záměrně jsme proto nepředložili do diskuze „hotový“ dokument, který jsme mohli jednoduše vytvořit kompilací zahraničních standardů. Uvedené př́klady profesních činností měly vést $k$ přemýšlení o podstatě kvalitní učitelské práce a ke kritickému přistupu k předloženým návrhưm včetně tvorby vlastních, především lepších řešení. Od začátku jsme zdůrazňovali, že se nejedná o první verzi standardu, ale pouze o nastartování veřejné diskuze. ( $V$ mnoha zemích byla tvorba profesního standardu několikaletým procesem, např. v Nizozemí trvala tvorba dokumentu celých 6 let).

Shodli jsme se na tom, že má-li mít profesní standard a jeho zavádění smysl a mají-li být naplňovány jeho funkce, je nutné vytvořit odpovídající podmínky.

Standard měl být vyvíjen seriozním zpưsobem (zejména byl nutný dostatek času) a za podstatného zapojení odborné i širší veřejnosti. Standard měl být formulován na takových úrovních náročnosti, které jsou reálně dosažitelné. Zejména v prvních fázích měl být považován za otevřený, vyvíjející se dokument, který bude pravidelně revidován. Měl by být zpočátku ověřován jako nástroj pro sebehodnocení učitelů a rámec pro profesní růst; tedy $v$ první fázi zejména jako nástroj podpory učitelů a ne jako nástroj kontroly.

Klíčovou podmínkou bylo, aby se podpora kvality učitelů a učitelského vzdělávání stala skutečnou (nejen proklamovanou) prioritou státní vzdělávací politiky. Konkrétním výrazem této priority mělo být vytvoření systému podpory učitelů a učitelského vzdělávání, zejména vytvoření ekonomických podmínek pro zajišt’ování kvalitního zavedení standardu a jeho dlouhodobou udržitelnost, což se nepodařilo.

Bylo třeba definovat legislativní podmínky - není možné zavádět standard, který má garantovat kvalitu učitelské profese, a současně neřešit problém vysokého počtu nekvalifikovaných učitelů (viz novely zákona petrifikující současný neutěšený stav). Stát měl aktivně a perspektivně řešit tento problém - např. finanční podporou fakult připravujících učitele rozšiřit možnost kombinovaných a distančních forem studia pro nekvalifikované učitele $z$ praxe. $V$ žádném př́padě není možné připustit, že by splnění standardu mohlo suplovat vysokoškolské vzdělání. 
Tvorba a zavádění standardu měla být v souladu s dalšími opatřeními vzdělávací politiky (např. koncepce př́pravného vzdělávání učitelů - role Akreditační komise při posuzování programů studia učitelství, systém dalšího vzdělávání pedagogických pracovníků, koncepce hodnocení České školní inspekce, podpora profesního růstu, kariérní rád). $Z$ těchto představ a podmínek bylo naplněno izolovaně a neprovázaně jen minimum.

Za velmi důležitý jsme považovali také dostatečný časový prostor na promyšlené vysvětlování a pozitivní medializaci profesního standardu učitele zacílenou k odborné pedagogické i rodičovské veřejnosti (vysvětlovat, že nejde o ohrožení a bič na učitele, ale o př́ležitost k oceňování kvality práce učitele, tak, jak je to obvyklé $\checkmark$ jiných profesích).

Zdůrazňovali jsme, že za nejdůležitější podmínku efektivní implementace Standardu považujeme vytvoření finančních a organizačních podmínek ze strany MŠMT pro využití standardu k profesnímu růstu učitelů (např. zavedení systémové kolegiální podpory ve škole, podpora začínajících učitelů, cílené další vzdělávání učitelů). Bez vytvoření systému komplexní podpory (zejména finanční) učitelů a učitelského vzdělávání nemělo smysl mluvit o zvyšování kvality učitelů a nemělo tedy ani smysl zavádět standard do praxe.

Přes velmi krátkou dobu se podařilo týmu v prosinci 2008, tedy asi po roce a půl od schválení koncepce př́pravy standardu na MŠMT, zveřejnit první verzi dokumentu s názvem „Tvorba Standardu profesní způsobilosti výkonu profesní činnosti učitele“. Diskuse ukázala opětovné obavy učitelů a veřejnosti před normativní podobou, která povede ke kontrole úspěšnosti učitele a ohrozí mnoho učitelů $v$ jejich perspektivě udržení si pracovních míst. Další část diskutujících podporovala myšlenku odsunu ideje standardu na pozdější dobu, až budou vytvořeny potřebné materiální podmínky. Jen malá část diskutujících pochopila, o co šlo, a věnovala se návrhům na proměnu formulací a jejich doplňování. Ve stejné době se začaly objevovat i zásadnější články odmítající Standard z principu. ${ }^{15}$

$V$ červenci 2009 zastavilo MŠMT ( $v$ čele již s ministryní M. Kopicovou) další financování prípravy Standardu kvality profese učitele. Z původního týmu se ale vyčlenila pracovní skupina, která dokázala zanalyzovat druhé kolo veřejné diskuse, jíž se zúčastnilo velké množství učitelů a škol. Přes léto a podzim 2009 byla zpracována druhá verze návrhu Profesního standardu kvality učitele a na www.standarducitele.cz byla zveřejněna řada dokumentů o zahraničních podobách standardů, Glosář s výkladem pojmů a Standard v otázkách a odpovědích i analýza veřejné diskuse. ${ }^{16}$ Druhá verze dokumentu Návrh pro tvorbu standardu kvality profese učitele se zapracovanými připomínkami z diskuse byl zveřejněn $v$ lednu 2010.17 Na jaře téhož roku již ale MŠMT připravovalo návrh individuálního národního projektu s názvem „Tvorba systému profesní činnosti učitele“, jehož cílem mělo být navržení systému podpory

15 Např́klad Hruška (2009)

16 Diskuse se zúčastnily nejdůležitější pedagogická sdružení a asociace (SKAV, APU, ADPF, AŘZŠ) a řada škol pomocí organizovaných seminářù s pomocí NIDV.

17 Učitelské noviny, 2010, č. 12, s. 15-18. 
20 profesního rozvoje učitele, zaměřeného na rozvoj celoživotního zvyšování kvality, navázaného na motivující kariérní rád a odpovídající systém odměňování, který měl vycházet $z$ výstupů jiného projektu v rámci OP VK, totiž z projektu Q-RAM se standardem absolventa pedagogických fakult. Přes ministerské proklamace o navazování na předchozí návrhy tvorby standardu $\mathrm{k}$ tomu nedošlo ani personálně, ani obsahově a pověřené pracoviště NIDV šlo svojí vlastní cestou. ${ }^{18}$

Nové koncepci prípravě standardu učitelské profese mohla pomoci i publikace J. Kohnové et al. z roku 2012, ale ideově už byly skupiny pracovníků z vysokých škol a z NIDV na různě odlišných stanoviscích (Kohnová et al., 2012).

\section{Závěrem}

Nový návrh standardu profese učitele z ledna 2014 málo reflektoval i doporučení OECD (Santiago et al., 2012), které vycházelo z důkladné analýzy a hodnocení vzdělávání v České republice, a ani výstupy z projektu „Cesta ke kvalitě“ (Tomková et al., nedatováno).

Objevují se negativní kritiky, vyjadřující opět „staré“ obavy z kategorizace učitelů na schopné a další, na dobré a špatné s důsledky $v$ jejich profesním působení. To je ale jen sekundární projev standardizace. Kdo bude schopen pracovat tak, aby neškodil dětem, a bude umět rozvíjet jejich nadání a schopnosti již jen motivací $k$ učení, nemůže být hodnocen špatně. Cesta však vede jen a jen přes vlastní reflexi učitelů. Nový návrh nerespektuje učitele jako tvůrce sebe sama a nevnímá jeho zvyšující se hodnotu pro děti a školu, nýbrž vlastním návrhem spojeným s kariérním postupem jej od dětí postupně odvádí a nabízí mu činnosti jiné. To nejen nesystémové, nemotivující, ale i neekonomické. ${ }^{19} \mathrm{~V}$ současné době návrh dokumentu přešlapuje a obě názorově odlišné skupiny čekají na reakci druhého tábora. Jak se podaří tento „gordický uzel standardizace“ rozseknout je věcí příštích týdnů. I novela školského zákona by měla respektovat perspektivní zájmy české společnosti a nekodifikovat pravidla nahrávající jen omezeným ekonomickým a politickým krátkozrace formulovaným zájmům, ignorujícím kultivační funkci vzdělávání. Meč $\checkmark$ ruce drží i současné vedení MŠMT, jistě pozorně studující výsledky mezinárodního šetření TALIS 2013, které byly nedávno prezentovány ČŠI. ${ }^{20}$ Pokud bude Standard činnosti učitele dále prosazován pro kariérní rád jako „útěk od práce s dětmi“, posílí se současný stav uspokojení učitelů. Cesta k efektivnímu zvyšování je jen a jen ve vytváření podmínek pro vyšši individualizaci procesů učení ve školách a tomu by měl být přizpůsoben také kariérní řád učitelské profese, umožňující to, aby nejlepší učitelé zůstávali u dětí.

\footnotetext{
18 Napríklad Špirhanzl (2010).

19 Copak být „jenom“ učitel nestačí? In: Učitelské noviny, CXVII, 2014, č. 10, s. 18-20.

20 UIV (2014). Dostupné na www.csicr.cz.
} 


\section{Literatura}

ČŠI. (2014). TALIS 2013. Praha: ČŠI.

Evropský rámec kvalifikací (EQF) pro celoživotní vzdělávání. (2005). Brusel.

Hruška, J. (2009). Kdo chce učit, může učit dobře i bez standardu. Školství, 17(18), 4.

Kohnová, J. et al. (2012). Profesní rozvoj učitelů a cíle školního vzdělávání. Praha: PedF UK.

Korthagen, F. (2004). Search of the essence of a good teacher. Teaching and Teacher Education, 10(1), 77-97.

Národní program rozvoje vzdělávání v České republice. Bílá kniha. (2001) Praha: ÚIV.

Profesní standard kvality učitele v otázkách a odpovědích. (2009). Školství, 17(11).

Rýdl, K. (2010). K vývoji správy a řizení školství v českých zemích I. (1774-1989). Pardubice, FF UPa.

Santiago, P. et al. (2012). OECD Reviews of evaluation and assessment in education: Czech Republic 2012. OECD Publishing.

Spilková, V. et al. (2010). Kvalita učitele a profesní standard. Praha: PedF UK.

Suchánková, K. (2007). Profesní standard a jeho role ve zkvalitňování učitelské profese. Orbis scholae, 1(3), 13-26.

Špirhanzl, P. (2010). Ve standardech jsme rok neztratili. Učitelské noviny, 114(18), 7.

Štefflová, J. (2014). Copak být „jenom“ učitel nestačí? Učitelské noviny, 117(10), 18-20.

Švec, V. (Ed.). (2002). Profesní růst učitele. Sborník příspěvků z 10. konference ČPdS. Brno: Konvoj.

Tomková, A. et al. (nedatováno). Rámec profesních kvalit učitele - hodnotící a sebehodnotící arch. Dostupné z www.nuv.cz/ae.

ÚlV. (1999). České vzdělání a Evropa. Praha: ÚlV.

Vašutová, J. (2001). Kvalifikační předpoklady pro nové role učitelů. In E. Walterová et al., Učitelé jako profesní skupina, jejich vzdělávání a podpưrný systém. 1. díl. (s. 19-46). Praha: PedF UK.

Věstník MŠANO, XIII, 1931.

Věstník MŠANO, XVII, 1935.

Walterová, E. et al. (2001). Učitelé jako profesní skupina, jejich vzdělávání a podpưrný systém. 1. a 2. díl. Praha: PedF UK.

prof. PhDr. Karel Rýdl, CSc., Katedra věd o výchově Fakulta filozofická, Univerzita Pardubice Studentská 97, 53210 Pardubice-Stavařov karel.rydl@upce.cz 